\title{
Jerzy Misiurek, Modlitwa. Medytacja. Kontemplacja. Mistyka. Dzieje problematyki, Lublin 2011, ss. 376
}

Błogosławiony Jan Paweł II, kierując do całego Kościoła powszechnego list apostolski Novo millennio ineunte na zakończenie wielkiego Jubileuszu Roku 2000, zaznaczył, że nowe tysiąclecie otwiera się przed Kościołem niczym rozległy ocean, na który należy wypłynąć, licząc na pomoc i obecność Chrystusa (zob. NMI 58). Nie można zapomnieć, że to On winien mieć pierwszeństwo w każdym podejmowanym dziele apostolskim. W życiu każdego człowieka istnieje bowiem pokusa koncentrowania się sobie samym. Rezultatem tego jestbłędne przekonanie - zresztą wielu osób, że owoce działań apostolskich zależą w głównej mierze od zdolności planowania oraz organizacji działania. Stąd też Jan Paweł II przypomniał słowa św. Pawła, mówiąc, że biada nam, gdybyśmy zapomnieli, że bez Chrystusa nic nie możemy uczynić (zob. NMI 38).

W ten sposób dochodzimy do modlitwy, która „ustawia” we właściwy sposób hierarchię wartości w życiu człowieka. To ona przypomina każdemu wierzącemu o pierwszeństwie Chrystusa i Jego łaski. Dzięki modlitwie człowiek zaczyna rozpatrywać swoje życie w perspektywie wiary i w ten sposób przyjmuje zaproszenie Boga do wejścia na drogę świętości. Ta zaś jest szczególnym darem Boga, ale i wielkim wyzwaniem. Nikt przecież świętym się nie rodzi, ale można żegnać ten świat, odchodząc do domu Ojca w opinii świętości. Można zatem stwierdzić, że świętość to nieustanne wzrastanie na drodze wiary; to nieustanne bycie w szkole modlitwy.
Jest to zatem droga współpracy z łaską Bożą, która w konsekwencji prowadzi do odkrycia, a następnie do przyjęcia Jego woli.

Pytanie o modlitwę to pytanie o styl życia. Istnieje $\mathrm{w}$ języku potocznym powiedzenie: Powiedzmi,jakty się modlisz, a ja cipowiem, jak żyjesz. I z pewnością jest w nim wiele mądrości. Modlitwa bowiem świadczy o duchowej kondycji człowieka.

W kontekst podejmowanej problematyki wpisuje się nowa pozycja książkowa, wydana w ramach Polskiego Stowarzyszenia Teologów Duchowości, autorstwa ks. prof. Jerzego Misiurka pt. Modlitwa. Medytacja. Kontemplacja. Mistyka. Dzieje problematyki. Ks. Jerzy Misiurek znany ze swej kompetencji, profesor historii duchowości daje współczesnemu czytelnikowi do rąk „kompendium" modlitwy chrześcijańskiej. Z wielką radością należy przyjąć fakt, że na polskim rynku wydawniczym pojawiło się długo oczekiwane, rzetelne studium poświęcone teologii modlitwy, medytacji, kontemplacji oraz dziejom mistyki chrześcijańskiej. Należy podkreślić, że pozycja ks. prof. Jerzego Misiurka ukazuje modlitwę zarówno w jej rozwoju historycznym, jak i aspekcie duchowym. Czytając ją, mamy do czynienia z głęboką refleksją teologiczną, która wprowadza nas w perspektywę doświadczenia relacji człowieka z Bogiem.

Pierwszy rozdział prezentowanej książki poświęcony został modlitwie. Autor omawia ją w kontekście historycznym, a następnie przechodzi do prezentacji jej struktury według 
tradycyjnego podziału na: modlitwę uwielbienia, dziękczynienia, przebłagania oraz modlitwę błagalną. Ważne miejsce w tej części zajmuje refleksja poświęcona modlitwie liturgicznej i różańcowej w polskiej duchowości katolickiej. Ponadto ks. Jerzy Misiurek zwraca uwagę czytelnika na modlitwę indywidualną i wspólnotową. W końcowej części rozdziału przedstawia wzory życia modlitewnego: św. Franciszka i św. Teresę od Jezusa, a także analizę Modlitwy Pańskiej.

$\mathrm{W}$ drugim rozdziale autor podejmuje refleksje nad zagadnieniem medytacji. Wyjaśnia jej znaczenie i wskazuje na jej obecność w Biblii, pierwotnym chrześcijaństwie, okresie średniowiecza, szkołach duchowości i w czasach współczesnych. Następnie ks. prof. Misiurek sięga do polskiej myśli teologicznej podejmującej zagadnienie medytacji. Wskazuje tu na podział medytacji, jej problematykę i owoce z nią związane. Dodatkiem, a raczej zwieńczeniem tego rozdziału, jest zwrócenie uwagi na świętość, która stanowi żywe świadectwo skuteczności Ewangelii.

Kolejny rozdział koncentruje uwagę czytelnika na zjawisku kontemplacji. Autor sięga tu do biblijnych korzeni kontemplacji, ukazując ją w perspektywie Starego i Nowego Testamentu. Następnie omawia jej obecność w dziejach Kościoła, z uwzględnieniem starożytności, średniowiecza, czasów nowożytnych i najnowszych. Ks. Jerzy Misiurek wskazuje przy tym na istotne aspekty kontemplacji nabytej i wlanej. Końcowa część rozdziału poświęcona została kontemplacji oblicza Chrystusa.

W ostatnim rozdziale podjęte zostało zagadnienie mistyki. Autor wyjaśnia jej pojęcie i omawia obecność doświadczenia mistycznego w życiu człowieka. Po tak nakreślonej problematyce ks. Jerzy Misiurek przedstawia obecność mistyki w Kościele katolickim w aspekcie historycznym. Osobna część tego rozdziału poświęcona została mistyce polskiej oraz doświadczeniu mistycznemu Maryi.

Nakońcu omawianego opracowania czytelnik może znaleźćpodsumowanie w języku angielskim, indeks osobowy, wykaz pierwodruków autora wykorzystanych w książce oraz wykaz skrótów.

Podsumowując, należy podkreślić, że omawiana pozycja ks. prof. Jerzego Misiurka jest niezwykle cennym opracowaniem, z którego może skorzystać każda osoba zainteresowana duchowością zarówno w perspektywie historycznej, jak i samego rozwoju duchowego. Jest to książka godna polecenia, mogąca ubogacić każdego czytelnika. Tym bardziej że jest pisana przez osobę cieszącą się wielkim autorytetem w dziedzinie teologii duchowości oraz uznaniem i szacunkiem wśród duchowieństwa i osób świeckich. Księdzu Profesorowi należą się zatem wielkie podziękowania za kolejne jego dzieło w zakresie historii duchowości. Wpisuje się ono w wielkie bogactwo polskiej myśli teologicznej.

Jacek Kiciński CMF 